\section{REFERENCES}

1 Tanaka G, Sandford AJ, Burkett K, et al. Tumour necrosis factor and lymphotoxin A polymorphisms and lung function in smokers Eur Respir J 2007; 29: 34-41.

2 Chappell S, Daly L, Morgan K, et al. Cryptic haplotypes of SERPINA1 confer susceptibility to chronic obstructive pulmonary disease Hum Mutat 2006; 27: 103-109.

3 Sinnwell JP, Schaid DJ, Yu Z. Statistical analysis of haplotypes. Version 1.2.2., http:/ / cran.r-project.org/src/contrib/ Descriptions/haplo.stats.html Date last update: June 2007.

4 SAS/Genetics User's Guide. Release 8.2. Cary, SAS Institute Inc., 2002.

5 Hersh CP, DeMeo DL, Lange C, et al. Attempted replication of reported chronic obstructive pulmonary disease candidate gene associations Am J Respir Cell Mol Biol 2005; 33: 71-78.
6 Higham MA, Pride NB, Alikhan A, Morrell NW. Tumour necrosis factor- $\alpha$ gene promoter polymorphism in chronic obstructive pulmonary disease Eur Respir J 2000; 15: 281-284.

7 Patuzzo C, Gilè LS, Zorzetto M, et al. Tumor necrosis factor gene complex in COPD and disseminated bronchiectasis Chest 2000; 117: 1353-1358.

8 Ruse CE, Hill MC, Tobin M, et al. Tumour necrosis factor gene complex polymorphisms in chronic obstructive pulmonary disease Respir Med 2007; 101: 340-344.

9 Küçükaycan M, Van Krugten M, Pennings HJ, et al. Tumor necrosis factor $\alpha+489 \mathrm{G} / \mathrm{A}$ gene polymorphism is associated with chronic obstructive pulmonary disease Respir Res 2002; 3: 29.

DOI: 10.1183/09031936.00057107

\title{
Beyond the "ABC approach"
}

To the Editors:

I read with interest the recent review by CELLI and BARNES [1], wherein the authors have beautifully discussed the aetiology, cellular and molecular mechanisms, management and new definition of exacerbations of chronic obstructive pulmonary disease (COPD).

In the management of acute exacerbations of COPD they have discussed the role of three classes of drugs (antibiotics, bronchodilators and corticosteroids, i.e. an "ABC approach"); however, the role of oxygen therapy, theophylline and supportive management is not mentioned. All of these have implications for the management of the disease.

Hypoxia at exacerbation of COPD is quite common and may be life threatening. The importance of controlled oxygen therapy during the management of acute exacerbation cannot be overlooked [2].

Theophylline is widely used in the management of stable patients with COPD. A recent meta-analysis evaluating the role of intravenous aminophylline in cases of acute exacerbation of COPD did not find any beneficial effect in terms of improvement of pulmonary function or symptoms [3]. However, the withdrawal of methylxanthines in patients already receiving them can worsen lung function, clinical status, exercise performance and ratings of dyspnoea [4]. Therefore, patients already receiving oral preparations of methylxanthines for stable disease should continue on such treatments at the time of exacerbation. The current Global Initiative for Chronic Obstructive Lung Disease (GOLD) guidelines even suggest adding aminophylline to standard therapy for patients with moderate-to-severe exacerbations or those not responding to nebulised short-acting bronchodilators [5].

Appropriate fluid balance (with special attention to the administration of diuretics), nutritional aspects, anticoagulants, and cardiovascular agents are the most complementary standard measures. Manual or mechanical chest percussion and postural drainage may be beneficial in patients producing $>25 \mathrm{~mL}$ sputum per day or with lobar atelectasis.

\section{A. Singh \\ Pulmonary and Critical Care Medicine, Christian Medical College and Hospital, Ludhiana, India.}

\section{STATEMENT OF INTEREST}

None declared.

\section{REFERENCES}

1 Celli BR, Barnes PJ. Exacerbations of chronic obstructive pulmonary disease Eur Respir J 2007; 29: 1224-1238.

2 Aubier M, Murciano D, Milic-Emili J, et al. Effects of the administration of $\mathrm{O}_{2}$ on ventilation and blood gases in patients with chronic obstructive pulmonary disease during acute respiratory failure Am Rev Respir Dis 1980; 122: 747-754.

3 Barr RG, Rowe BH, Camargo CA Jr. Methylxanthines for exacerbations of chronic obstructive pulmonary disease: meta-analysis of randomised trials BMJ 2003; 327: 643.

4 Kirsten DK, Wegner RE, Jörres RA, Magnussen H. Effects of theophylline withdrawal in severe chronic obstructive pulmonary disease Chest 1993; 104: 1101-1107.

5 Rabe KF, Hurd S, Anzueto A, et al. Global Strategy for the Diagnosis, Management, and Prevention of Chronic Obstructive Pulmonary Disease-2006 Update. Am J Respir Crit Care Med 2007; [Epub ahead of print PMID: 17507545].

DOI: $10.1183 / 09031936.00072207$ 